\title{
GENDER MAINSTREAMING IN SPAIN: THE CASE OF THE "LIDERA PROJECT" IN THE AUTONOMOUS REGION OF MADRID
}

\author{
Lourdes Susaeta \\ José Ramón Pin \\ Trinidad Yera \\ Angela Gallifa \\ Esperanza Suarez
}




\title{
GENDER MAINSTREAMING IN SPAIN: THE CASE OF THE "LIDERA PROJECT" IN THE AUTONOMOUS REGION OF MADRID
}

\author{
Lourdes Susaeta', José Ramón Pin², Trinidad Yera', \\ Angela Gallifa ${ }^{3}$, Esperanza Suarez ${ }^{1}$
}

\section{Abstract}

Women continue to be under-represented in senior positions. The disparity is widest at the very top, where only 3\% of companies have a woman directing their highest decision-making bodies (Iversen and Frances, 2010). In this paper, we present a "best practice" implemented by public agents as key actors for gender mainstreaming. Gender mainstreaming as a strategy is meant to actively counteract this gender bias, and to use policymakers' standing mandate to promote more equitable relations between women and men (Verloo, 2000: 13). The rationale for pursuing gender mainstreaming via the Structural Funds is as much about promoting economic efficiency as it is about promoting equity. In this paper, we analyze a specific case launched three years ago by the Government of the Region of Madrid, the "Lidera project". The main objectives pursued by this initiative are to enhance women's professional opportunities and facilitate their access to leadership positions in companies. We focus our study on the impact of the Lidera Scholarships initiative, which consists of granting scholarships for management study programs at the top business schools in Madrid. Now that several years have passed since implementation of the Lidera project, it is time to analyze its impact and effectiveness, that is, to assess the overall effectiveness of the gender mainstreaming effort through the Lidera project. We analyze the impact at the macro level of analysis and at the individual level through five constructs: Professional Improvement; Working Conditions; Labor Market Perception; Management Training; and Work and Family Balance. We can conclude at the individual level that the LIDERA EFFECT exists and it has a positive and differential impact on three of the five constructs. At a macro level, there is some impact on female unemployment and the level of competitiveness of the Region of Madrid. We can therefore assume that government efforts to assign structural funds to improve management education for women have exponential results. This case shows the evidence for the particular case of Madrid, but the positive results of this initiative carried out by political actors could be a best practice applicable to other Latin American countries.

Keywords: Gender Mainstreaming, Autonomous Region of Madrid, Glass ceiling.

\footnotetext{
${ }^{1}$ Researcher, IRCO-IESE

${ }^{2}$ Professor of Managing People in Organizations; José Felipe Bertrán Chair of Governance and Leadership in Public Administration, IESE

${ }^{3}$ Manager, IRCO-IESE
} 


\section{GENDER MAINSTREAMING IN SPAIN: THE CASE OF THE "LIDERA PROJECT" IN THE AUTONOMOUS REGION OF MADRID}

\section{Introduction}

Women continue to be under-represented in senior positions in many fields despite the fact that they make up nearly half of the workforce and more than half of new university graduates in the European Union. Only one out of 10 board members of the largest companies listed on the national stock exchanges of EU Member States is a woman and progress has been slow in recent years. The disparity is widest at the very top, where only 3\% of such companies have a woman directing their highest decision-making bodies (Iversen and Frances, 2010). If Europe is to achieve its goal of becoming a dynamic, competitive, knowledge-based economy in a globalized world, European institutions and social agents face the challenge of making better use of women's talents and skills. The problem at the moment is that the few women holding senior management positions are perceived as outsiders and this fact creates a false (male) stereotype of what is required to be a leader. Male leaders tend to be associated with "agentic" behavior: they are more likely to be proactive, assertive, and dominant, in control of the situation. However, female leaders, by contrast, show what we call "communal values": friendliness, support, warmth and a caring attitude (Chandler, 2010). There is an increasing body of research showing that gender diversity pays off and that there is a positive correlation between women in leadership and business performance (Dunphy, 2004). Decision-makers also appear to have a limited awareness of the growing force of demographic changes currently taking place in the workforce that significantly affect human resources. Furthermore, many decision-makers appear to be unaware of the potential benefits of diversity or the negative outcomes of discrimination at work that can affect every aspect of management and organizational functioning.

\section{Theoretical Background}

There is no doubting that the female population of Spain has had a lot of catching up to do. The four decades of dictatorship following Spain's civil war kept women in traditional roles far longer than other Europeans, and they trailed far behind women in the United States and Britain, who gained substantial ground during World War II when they filled in for men away at battle. Even now, less than 3\% of top management in Spain's listed companies is female. 
However, in recent years, Spanish women have made substantial progress in business, politics, and the judiciary. Now, with new laws on the way designed to increase their power in business, they may be on the verge of finally breaking the glass ceiling. Currently, public agents are developing new strategies to facilitate this process. A critical part of this process is gender mainstreaming, which True and Mintrom (2001:28) defined as the effort to scrutinize and reinvent policy formulation and implementation processes across all issue areas to address and rectify persistent and emerging disparities between men and women. This is a "new" and more promising, transformative, even "revolutionary" strategy (see also: Hafner-Burton and Pollack 2000: 3; Rees 1998; Rees 2000).

By this means, gender equality can become a concrete reality in the lives of women and men, creating space for everyone both within organizations and in communities, so that they can contribute to the process of articulating a shared vision of sustainable human development and translating it into reality (Mclnerney et al., 2010). Gender mainstreaming was originally launched in 1996 to promote gender equality in all EU policies, in the context of international and European mobilization around equality for women. It aimed to transform mainstream policies by introducing a gender-equality perspective in European policy-making. Gender mainstreaming as a strategy is meant to actively counteract this gender bias, and to use the standing mandate of policymakers to promote more equitable relations between women and men (Verloo, 2000: 13). It addresses "systems and structures themselves - those much institutionalized practices that cause both individual and group disadvantage in the first place" (Rees 2000: 3). 'Mainstreaming equality' is considered to be one of the three major tools of sex equality policies, together with equal treatment legislation and positive action in favor of women (Kelan and Jones, 2010). Gender mainstreaming does not rely on law enforcement mechanisms but instead involves a long-term transformation of public policies (Pollack and Hafner-Burton 2000; Liebert 2003). Stressing the danger of weakening gender equality policies as a whole - as a result of gender mainstreaming implementation - (Verloo, 2001) argues that, given the power relations existing between the genders, gender mainstreaming becomes a political process in itself.

The adoption of gender mainstreaming implied that it was no longer acceptable to assume that additional resources aimed at stimulating economic development and growth benefited men and women equally. Therefore, in order to maximize the economic impact of policies designed to stimulate regional development, they needed to be more 'gender aware'. This is what gender mainstreaming is attempting to achieve, by bringing gender equality considerations to the mainstream policy development and delivery process. The rationale for pursuing gender mainstreaming via the Structural Funds is as much about promoting economic efficiency as it is about promoting equity.

\section{The European Social Fund in Spain, 2007-2013}

Spain is using ESF funding to address some of the main challenges it faces: improve its human capital, foster entrepreneurship and increase female participation in the labor market, and promote employability, social inclusion and equal opportunities among men and women. With an eye to improving its economy's low productivity, Spain is also funding more research and innovation as well as schemes to boost participation in education and lifelong learning. 
The Spanish economy was severely hit by the crisis and went through a sharp adjustment in 2008-2009. Real GDP fell by 4.3\% between the beginning of 2008 and the end of 2010.

Employment dropped sharply during the crisis, while wages reacted only with a lag. As a result, unemployment rose to be the highest in the eurozone. From a low of $8.25 \%$ in 2007, the unemployment rate reached a record high of $21.25 \%$ in the first quarter of 2011 , in spite of the fact that the fall in the GDP during the crisis was less severe than in other eurozone member states. The young, the less qualified, and less experienced workers, many of them on temporary contracts, bore the brunt of the recession. Youth unemployment reached 41.6\% in 2010. Men were more affected than women. However, there is still a significant gap between men and women in activity and employment rates, as recognized in the NRP. The construction sector suffered the largest employment losses, with more than half of the overall increase in unemployment coming from this sector. This major sectoral reallocation of employment poses a risk of skill mismatches. Labor-shedding affected to a greater degree workers with temporary contracts. While representing about one quarter of total employees, temporary employment accounted for about 90\% of the net reduction in total employment between the first quarter of 2007 and the end of 2010.

Spain's ESF strategy seeks to foster employment stability and improve workers' adaptability. With schemes to nurture new businesses and strengthen lifelong learning in the workplace, the country intends to build on its growth and employment rates.

Furthermore, the strategy aims to improve opportunities and working conditions for groups such as migrants and women - with a view to integrating them into the workforce as well as helping them to get better, more qualified jobs. This involves courses, particularly training in ICT and organizational skills, to enable easier access and return to work, especially for disadvantaged groups. It also means persuading employers to establish more flexible working patterns to help parents balance the demands made on them by their employment and their family environment. Spain also plans to reform its education and training structures, investing more in research and innovation while also doing more to encourage attendance at university and vocational training courses. These plans are essential for the country: first, to compete in the global knowledge economy; second, to forge a skilled and inventive workforce - and ultimately to ensure healthy productivity and competitiveness. Among the priorities that apply to the social funds of the European Spain joined we can highlight two priority which have the following aims:

- Enhance employability, social inclusion and equal opportunities for men and women.

- Modernize and strengthen labor market institutions and establish proactive and supportive measures on the job market.

- Improve access to jobs and boost the long-term development and employment of women and migrants. Organize return-to-work courses for disadvantaged groups.

- Promote partnerships, agreements and initiatives by establishing networks among relevant organizations.

- Improve the formulation, follow-up and assessment of policies and programs.

This priority provides the framework for applicability of European social funds to the Region of Madrid's Lidera project, especially with respect to the promotion of equal opportunities for women in the labor market. 


\section{What is the Lidera Project?}

The Autonomous Region of Madrid is one of the 17 regions into which Spain was divided constitutionally with the advent of democracy in 1977. The Region of Madrid has more than six million people and includes the capital, Madrid, and a number of industrial and dormitory towns. For fifty years, Madrid has been a government administration center in financial, industrial and service sectors. For nearly 20 years, this Region has been governed by the Popular Party, a center-right party. For two terms, its President has been Mrs. Esperanza Aguirre, one of the few and first female politicians in Spain to have held the office of President of the Senate and Minister of Education and Culture since the return of democracy. The Government of the Region of Madrid, Mrs. Esperanza Aguirre and her team launched the "Lidera project" three years ago ${ }^{1}$ with the primary goals of furthering women's professional opportunities and facilitating their access to leadership positions in companies. Lidera is an ambitious program of guidance, training and career advice, targeting all women living in the Region of Madrid who are interested in developing their leadership skills. Lidera consists of two initiatives:

- Lidera Scholarships: Scholarships for graduate study programs at the top business schools.

- Lidera Skills: Training programs in leadership skills that are developed in three phases, seminars, workshops and individual coaching, always with the support of trainers and women who are first-rate professional references.

All participants in the program are part of the Lidera network, which strengthens the central role of women and enhances their personal and professional development through various services.

In this paper, we focus on the impact of the initiative's Lidera Scholarships, organized with the collaboration of the top business schools established in their territory. The Lidera scholarships cover $70 \%$ of the tuition fees for qualified professionals who pass the institutions' selection process for postgraduate courses, master courses and business education training. We can find empirical support for this initiative in a study recently undertaken by Slater and Dixon-Fowler (2010), in which the authors state: "CEOs with MBAs are making a positive contribution to the environmental sustainability of the planet”.

In this sense, the "Lidera Project" is based on the belief that business school education provides the fastest path to equal opportunity and breaks the famous glass ceiling for the female gender. Once they have completed this training period, they are more likely to be promoted to the top levels of their companies' organizations or to move to other areas. Quintanilla et al. (2008) concluded that Spanish business schools and their MBA programs dominate business education. Globalization is a reality, which is why the leading Spanish business schools offer international MBAs. Furthermore, 4 Spanish business schools rank among the top 100, according to the Financial Times' 2011 listing of MBA programs.

\footnotetext{
${ }^{1}$ Program funded by the European Social Fund. 
Based on the above, we would expect the main forces for the project's success to be those shown in Figure 1.

\section{Figure 1}

Lidera Main Forces

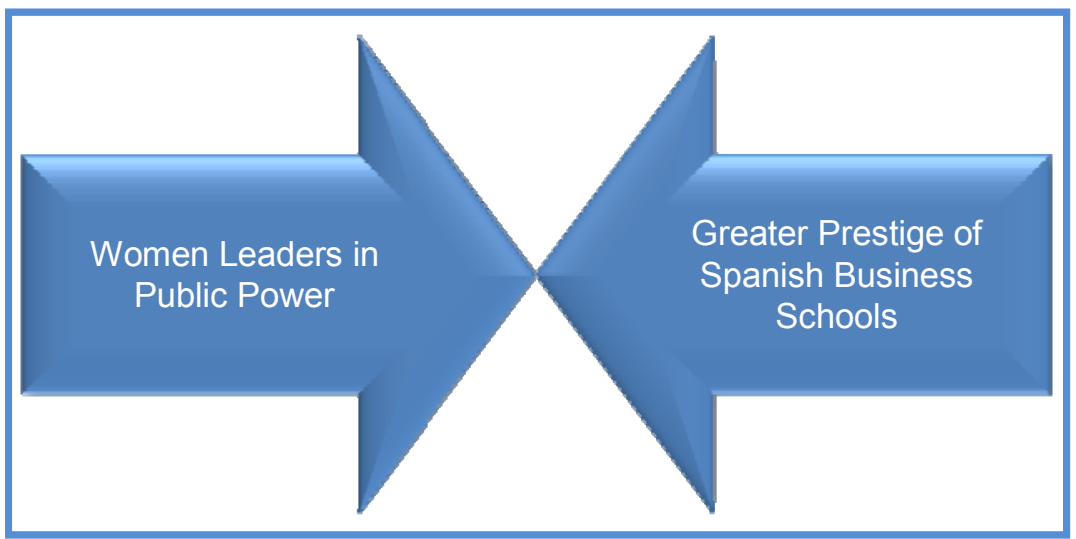

The president of the Region of Madrid, the project's managers, program directors and business school professors are all actively engaged with the project.

These key players will be the responsible for obtaining a perfect and revolutionary balance for achieving Lidera's Revolutionary Objectives (Figure 2).

\section{Figure 2}

Lidera's Revolutionary Objectives

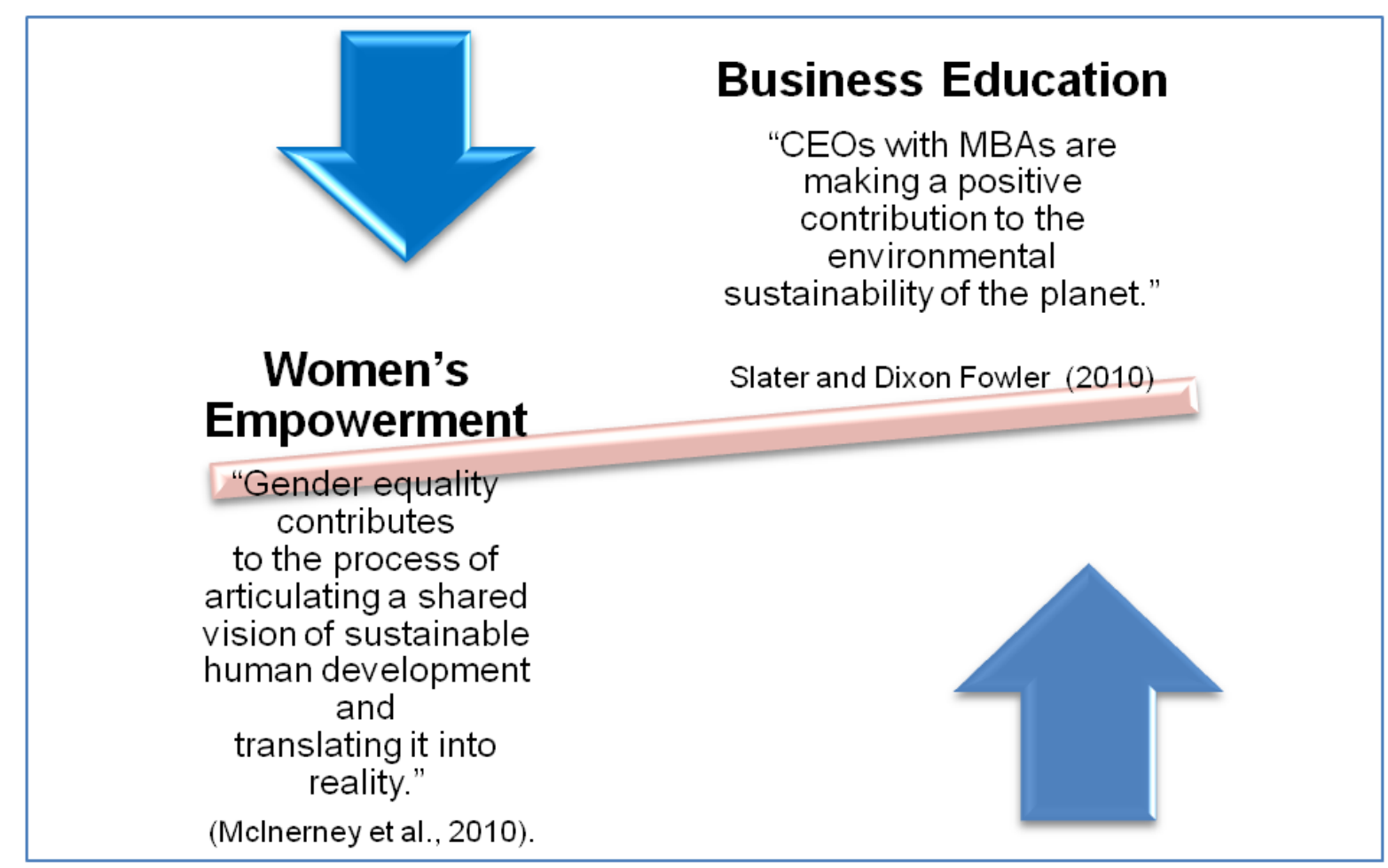




\section{Research Objectives}

Gender mainstreaming requires an investigation of gendered societal processes and outcomes, as embodied in policy implementation and results. Now that several years have passed since the Lidera project was implemented, the time has come to analyze its impact and effectiveness. In this paper, we highlight the role of individual key players, politicians and government officials in specific political and administrative decisions.

As the purpose of mainstreaming is to alter the existing social and political order that leads to gendered outcomes, the first research objective is to analyze the impact of the Lidera project, that is, to explore the changes in domestic norms and institutions arising from the Lidera project's gender mainstreaming efforts and to assess the overall effectiveness of the gender mainstreaming effort deployed through the Lidera project. More specifically, we would like to investigate the link between appropriate training and advancement up the corporate ladders of major global businesses (Devon and Grayson, 2005). Consequently, the paper's second research objective is to investigate the link between the improved education provided through the Lidera project and the advancement of women in corporate settings in Spain.

Summarizing, we would first like to investigate the institutional effect arising from gender mainstreaming efforts embodied in public policies and the reasons for and the effects of the Lidera project in the Autonomous Region of Madrid; second, the link between public scholarships for appropriate training and advancement up the corporate ladders of major global businesses; and, lastly, the possible existence of a relation between the improved education provided through the Lidera project and the advancement of women in corporate settings in Spain, giving we have called the LIDERA EFFECT.

\section{Methodology}

We analyze the case of the "Lidera Project" developed by the Autonomous Region of Madrid in Spain. The project, promoted by the Regional Government of Madrid in collaboration with the main business schools operating in this geographical area, provides valuable insights into public policies for gender mainstreaming. With this project, the Autonomous Region of Madrid seeks to promote women's integration in the labor market and improve the role of women in senior positions of responsibility. In the framework of local equal opportunity schemes between women and men promoted by the European Union, the government of Madrid is giving grants to Madrid women to study at the top postgraduate business schools. The primary aim is to promote women's integration in the labor market and improve their position in organizational hierarchies by overcoming the obstacles posed by gender-based discrimination and segregation.

We propose to evaluate the Lidera project's efficiency by applying a mixed approach based on quantitative and qualitative evaluation methodologies. We will use quantitative data to specify how well the program's goals were met (Sleezer and Spector, 2006) and qualitative methods to investigate the big picture from the viewpoint of the impact made by the project's stakeholders. Combining the two methods can often improve the richness of the results and make them more meaningful to decision-makers. To cover the quantitative aspect, we propose to compile data for the project's main parameters: Percentage of EU funds allocated by the Region of Madrid to the "Lidera Project" and to the scholarships in particular; budget, requirements, descriptive characteristics of the final beneficiaries, duration, and total cost of the project. To cover the 
qualitative aspect, we propose to conduct semi-structured interviews with the women who are the key players in the project.

Investigation of the first objective will be based on secondary sources (press, European Union reports, EIRO, and the Region of Madrid's website).

However, our research will be focused primarily on the second objective. Figure 3 shows the various stages that the project will complete in order to give an answer to our research objectives.

\section{Figure 3}

Research stages

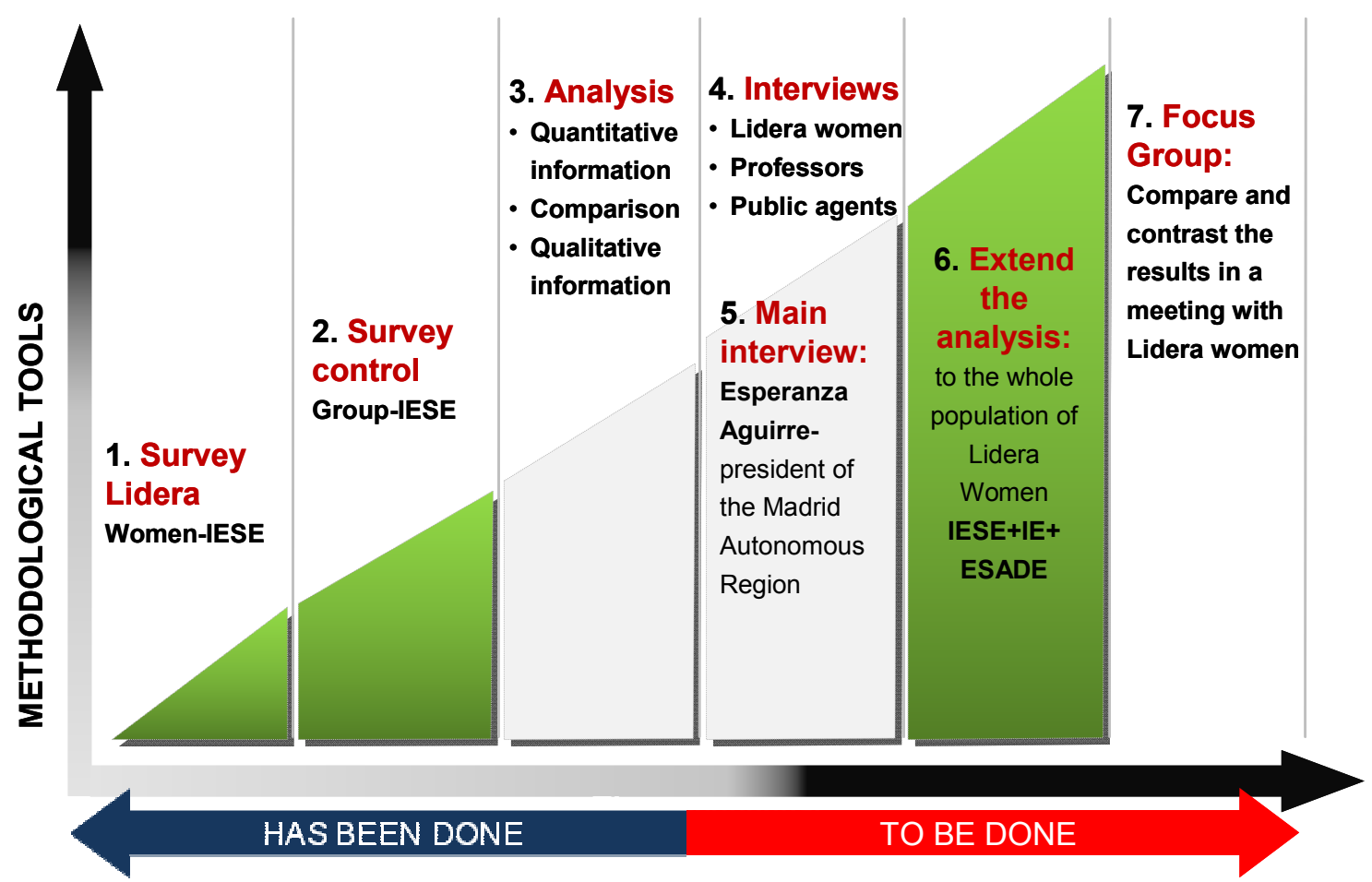

As we can see in Figure 3, the project is very ambitious. However, in this paper, we will limit our study to answering the research questions based on information obtained in the three first steps. Future research will help us complete the ultimate reason behind these results. Mixed quantitative and qualitative approaches cross at least two of the research stages. To answer the first research question, we used secondary sources and to answer the second question, we used an open questionnaire which brought quantitative and qualitative results. 


\section{The First Subpopulation and Subsample}

In the first stage of the research for this paper, we intend to give an initial answer to the research objectives using data from the "Lidera project" women who have enrolled in management programs at IESE Business School, covering the first three research stages.

Of the total number of beneficiaries of "Lidera" scholarships, 180 women have taken part in IESE programs over the 5-year period (2006-2010), with a total cost of €3,729,480.

We received 64 valid responses from the survey of the subsample composed of participants in IESE programs funded by Lidera, giving a response rate of 35.5\%.

\section{Constructs and Measures}

The survey data were analyzed using the construct method. First, "constructs" are built from the survey questions or items. Each construct may refer directly back to an overarching goal of the program being evaluated, such as "Professional improvement". We simply select all the survey items used to measure improvements in the Lidera women to create our constructs. Next, in order to analyze our constructs, the survey items within our construct are "collapsed" or summed to create a new variable.

Being a complex abstraction, constructs are not directly observable. Therefore, in this research, we use indicators or variables to measure or classify most of the constructs' items.

We have identified five constructs that represent different areas of improvement obtained by the women receiving the scholarships and that positively affect their professional and personal life:

Professional improvement; Improvement in working conditions; Improvement in Labor Market perceptions; Improvement in Management training and Improvement in Work-Life Balance.

\section{Descriptive Analysis}

We used a questionnaire whose variables are measured using a Likert scale from 1 to 5 (Disagree to Agree). The variables comprising each construct are discussed in the Results section on the descriptive analysis. We subsequently performed a construct validation to answer the question "Which constructs account for the variance in test performance?". The alpha coefficient for the items of the five constructs is between 0.730 and 0.839 , suggesting that the items have a relatively high internal consistency.

We constructed a mean ranking (numerically speaking) for each construct in order to ascertain the items that were most highly developed by the business training program for the Lidera women included in the sample.

\section{Experimental Method}

Experimental research is commonly used in sciences such as sociology and psychology, physics, chemistry, biology and medicine, etc. It is a systematic, scientific approach to research in which the researcher manipulates one or more variables, and controls and measures any change in other variables. Experimental Research is often used when we can predict a consistent causal relationship (a cause will always lead to the same effect). We can distinguish the Experimental group - the group that receives the experimental treatment condition to the Experimental control - eliminating any differential influence of extraneous variables. 
We used an experiment to try to isolate the effect of the Lidera scholarship. We took a control group with similar characteristics to those of the people who answered the survey, i.e., female gender, had followed a program at IESE, but had not received a grant for the program. The next step is to look for statistically significant differences between the means of the experimental and control groups.

In our case, the study endpoint was the existence of a causal relationship between receiving the grant and the rating of the construct variables.

\section{Results and Discussion}

As democratic theorists have long observed, quality education is a vital component of citizenship, reducing the barriers to individuals' participation in public discussion, deliberation, and debate over matters of public policy. The postgraduate qualification is increasingly seen as a prerequisite for senior posts (Baruch and Peiperl, 2000) and for many women, as a way of breaking through the glass ceiling (Burke, 1994; Leeming and Baruch, 1996). Business schools are a central agency for the secondary socialization of business people. For this reason, we expected that a greater proportion of women holding senior positions in public and private organizations would lead to an improvement in the quality of leadership over time. Linking to the objectives defined earlier, we expect the findings to shed some light on objectives 1 and 2, starting with objective 2, and, as a result, to show how the advancement of women reflects on the overall effectiveness of the gender mainstreaming effort through the Lidera project.

\section{Research question 1: Effectiveness and institutional impact of the Lidera Project}

The evaluation of public policies is an issue of great interest for policymakers and for society as a whole. It is the key instrument for judging a given action's degree of success or failure, and it can be used by regulators to make improvements in how public programs are designed and/or managed.

Impact evaluation centers on the degree of achievement of the main objectives by a given action, and it can bring added precision to the definition of the initial objectives themselves.

Over the last decades, Structural and Cohesion funds have proved to be very successful in increasing social and economic cohesion in the EU and, they pursue similar outcomes for the next seven years of programming. Given this circumstance, the timing of the seminar is very appropriate.

Over the period 2007-2013, some $€ 75$ billion will be distributed to the EU Member States and regions to help them achieve their goals.

EU employment, social affairs and inclusion policy interventions build on broad European policy objectives supported by economic and social 'needs-oriented' policies (see the European Social Agenda and the Europe 2020 strategy). They also take into account the evidence gathered from the results and impacts (positive or negative) of previous interventions. 


\section{Women and Jobs}

Equality between women and men is a fundamental principal of our democratic society. It is an important element of the EU 2020 Strategy, and essential if the European Union is to maintain its prosperity.

Despite the increasing presence of women in the labor market and in higher education, differences in the situation of men and women still persist. The ESF has already made important contributions to improving the situation of women in the labor market. For example, it has contributed to reducing the gender pay gap, from as high as 40\% (in the 1960s) to less than $20 \%$ today. Whilst this is good progress, clearly these efforts must continue.

The importance attached to ensuring gender equality in employment is reflected in the ESF programming for 2007-2013. Two approaches are used:

- Gender mainstreaming, which incorporates the gender dimension into all ESF priorities

- Specific actions aimed at getting women into work and keeping them there

The gender mainstreaming approach means that particular attention must be paid to equal opportunities in the programming and implementation of all ESF activities. Where possible, they support the promotion of women in employment and the elimination of pay differentials. Specific actions target women's employment directly - for example, by concentrating on a particular group such as immigrant women or women entrepreneurs. As well as promoting equal opportunities, the aim of this ESF priority is to raise the average level of women's participation in the workforce.

The European Commission's Directorate General for Employment, Social Affairs and Inclusion sets an evaluation calendar for assessing the contribution of its policy instruments (specific funding programs, legislation, policy processes....) to the objectives set by the EU. All of its evaluation activities are scheduled in the (multi-annual) evaluation plan.

In general, impact is the last 'stage' in a process. A good definition of impact is that given by Millard and Shahin (2006): 'General objectives (impacts): These are the overall goals of a policy and are expressed in terms of its ultimate impacts. These will not normally be expressed as Government objectives, but rather as societal objectives to which successful Government development should contribute, such as economic growth, jobs, democracy, inclusion, quality of life, etc.' Implementing Government always means allocation of means: people, budget, etc,... in a changing environment.

A second central concept is 'regional strategic behavior'. This research will focus on the strategic behavior of the regions in a domestic state reform. Since research about regional strategic behavior in multi-level polity contexts is largely non-existent, this project has a strong emphasis on this dependent variable and the first aim is to describe the different types of strategic behavior that regions use. The second step is to understand and explain the regional strategic behavior chosen. We will test the explanatory power of the institutionalist insights to understand the regional strategy choice in both the policy and institutional issues of domestic state reform. 
Within this framework, we could only assess the impact of the Lidera Project in the following aspects:

1) The unemployment rate in Madrid (16.1\%) is more than 4.5 points below the national average for women (20.7\%) and almost four points below the national average for men, according to the Deputy Minister of Employment and Women. More than 1.3 million women currently work in Madrid, compared with 620,000 in 1995 and the Region of Madrid has the greatest labor market parity in Spain - 47\% of the total people employed in the Region are women ${ }^{2}$.

2) The Regional Government develops programs such as LIDERA, a pioneering initiative in Spain whose purpose is to promote the leadership of women and facilitate their career in management. This program includes initiatives such as Lidera scholarships, which has allowed 586 women to follow postgraduate master programs in Spain's top business schools, or Lidera skills, providing leadership training and professional counseling that has benefited 3,300 women in Madrid.

3) The Regional Government of Madrid encourages self-employment as an alternative to paid employment through the Lidera program, an initiative that promotes women's leadership and which has included almost 4,000 women. ${ }^{3}$

4) Creation of the Lidera Network: The Lidera network includes all participants in the Lidera program (Lidera skills and Lidera scholarships). It aims to create a network of female professionals who can interact and cooperate with each other with a shared purpose: their own personal and professional development. It includes various services grouped into three broad categories.

5) Online Social Network. This is the platform that supports the Lidera Network, offering a number of services for managing the relationship between members of the Lidera Network: Profiling, contact management, private mail, messaging, etc.

Summarizing, women's effectiveness in positions of responsibility is a scientific fact: a study by McKinsey \& Company in 2010 shows that companies with a higher percentage of women in executive committees have 41\% more yield and 56\% more profit margin than companies without any women in top management. Their colleagues and bosses praise women's organizational skills and leadership and recognize the importance of management teams that take into account diversity and gender equality.

However, women are still far from being the norm in managerial positions in companies and in the technology sector, this trend is even more pronounced. Despite the legal protection provided by the Equality Act of 2007 and the recent European Union initiatives in favor of the so-called political quotas for women, the silent revolution progresses very slowly. The figures support the evidence: In the companies listed in the Ibex stock index, only 10\% of Board directors and 6\% of Executive Committee members are women. Furthermore, many of them owe their positions to inheritance of the family business.

\footnotetext{
${ }^{2}$ D. G. de la Mujer 04/08/2011.

${ }^{3}$ Idem 28/02/2011.
} 
The current economic crisis does not help matters. The quarterly survey carried out by Grant Thornton shows that the percentage of private sector companies with no women in top management increased to 38\% from 35\% in 2009.

Research objective 2: Link between publicly-funded scholarships for appropriate training and advancement up the corporate ladders of major global businesses

\section{Descriptive Results and Constructs}

In this section, we address the most significant items that female respondents have highlighted as a result of their participation in the Lidera program, ranked by the five constructs presented.

\section{Professional Improvement}

Professional improvement or development is essential for every individual, whether employed or not. All business and professional organizations need to increase their employees' knowledge and skills. To ensure personal and professional growth, they should strive to improve the quality of performance. We can define this construct in general terms as the process of obtaining the skills, qualifications, and experience that allows one to progress in one's career.

\section{Figure 4}

Professional improvement (percentage)

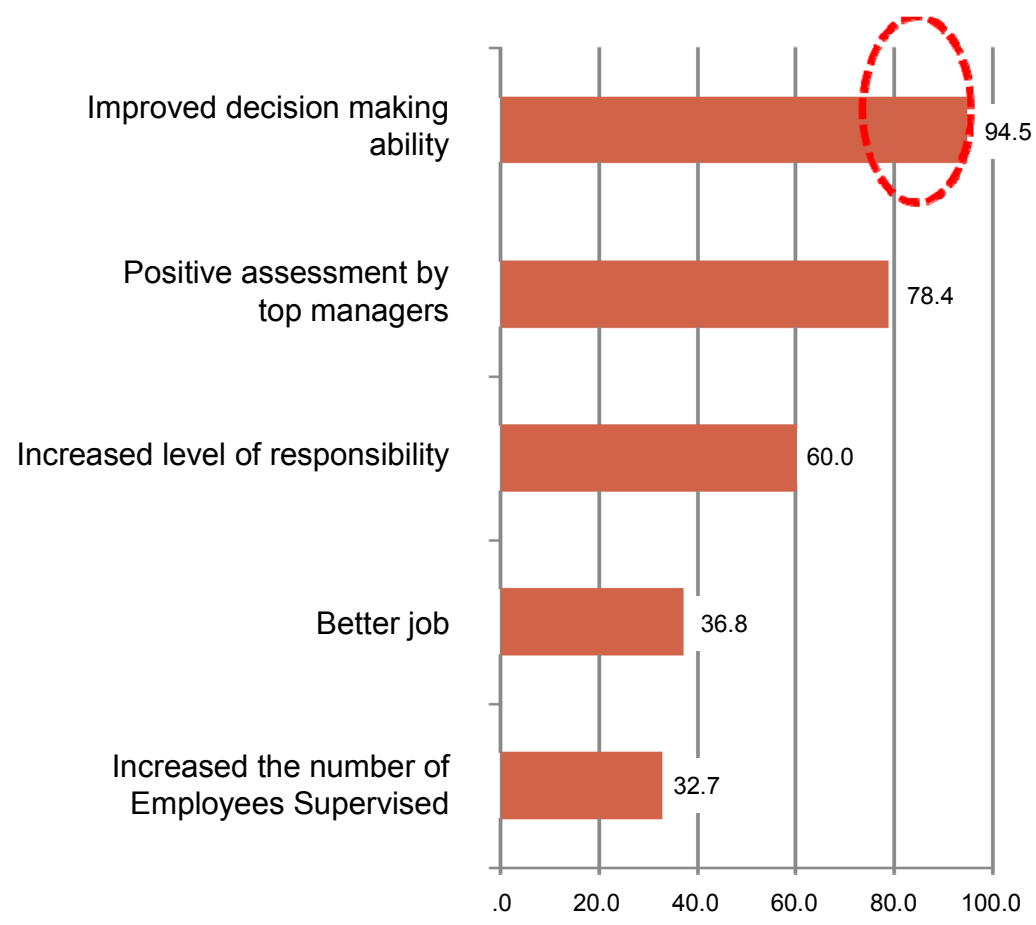


These results are supported by comments received from female respondents in the same survey:

"Professionally, my flexibility has improved. It has given me another view of the company that is much more enriching and it has improved my career prospects in the short term. Personally, it is brought me analytic skills, serenity and balance in decisionmaking (which allows me to handle situations that previously used to stress me), and, above all, solid values."

The construct variables that are rated highest are Decision-making and Assessment by top managers. Those rated lowest were the Possibility of finding a better job and the Possibility of supervising more employees, which implies an increased level of responsibility.

\section{Improvement in Working Conditions}

In order to perform a managerial job successfully, the individual must be able to perform each essential responsibility satisfactorily and another extrinsically motivations such as the salary, flexibility and so on.

\section{Figure 5}

Working conditions (percentage)

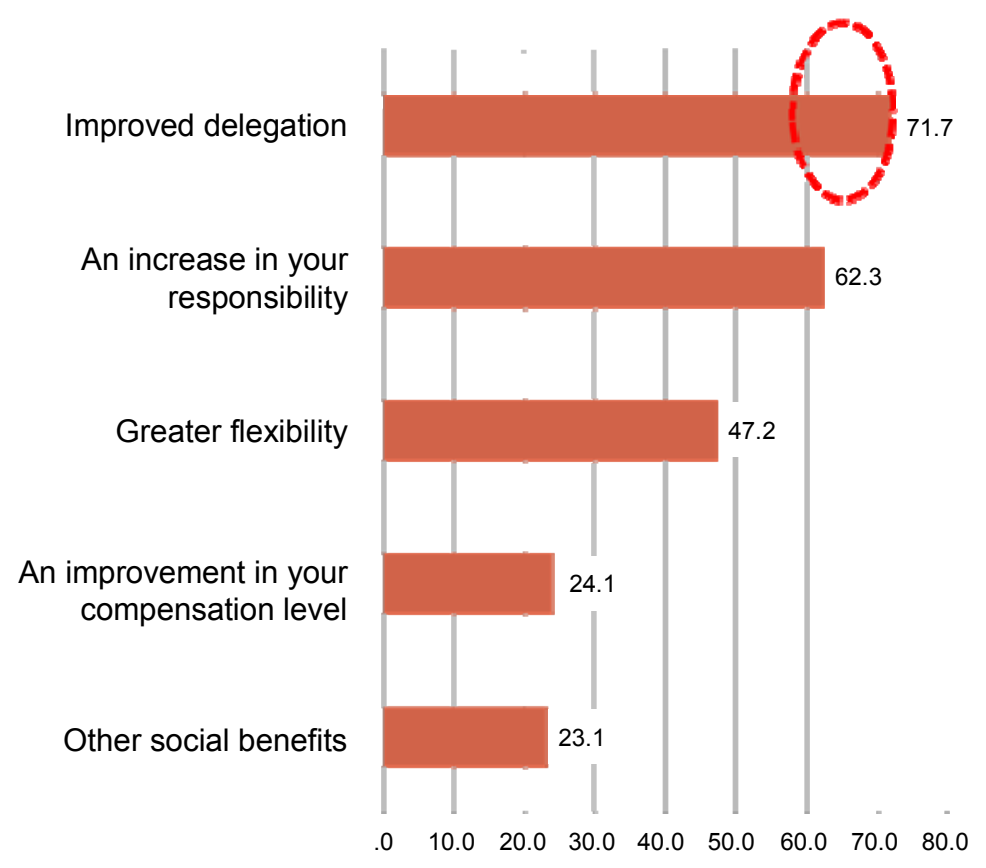

We found that the most significant item for this construct was the increased capacity for delegation.

\section{Labor Market Perception}

The differences in the perception of the causes of unemployment between men and women is symptomatic and consistent with survey findings that women are less interested in politics, political mechanisms and the principles of functioning political institutions (Randall, 1982; Siemieñska, 1990). 
New policies were needed, since welfare, gender contract and labor market policies were based on the male breadwinner model (Rees, 1998, p.179). In the present paper, we measure labor market perceptions using the items shown in Figure 6.

\section{Figure 6}

Labor Market perception (percentage)

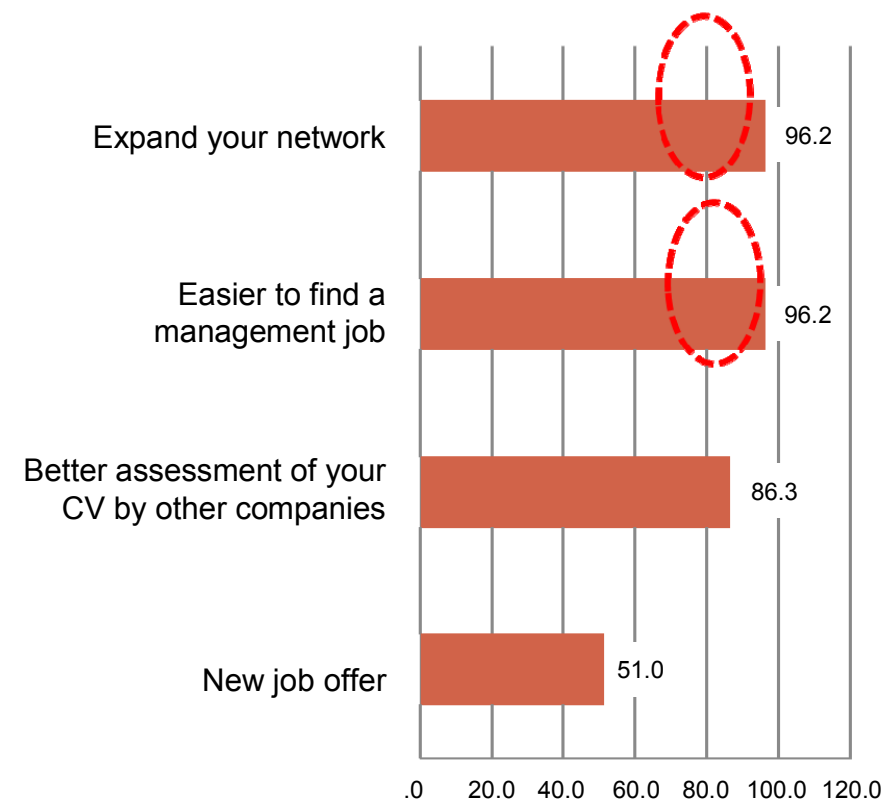

On this subject, one Lidera woman has said:

"For me it was partly a personal challenge and partly a need to learn and interact from a professional viewpoint with managers from other industries other than the finance sector in which I work"

Another said:

"A full experience that has enriched my knowledge of technical issues, networking, aspects of professional organization and improved my positioning in the labor market. Personally, I met some great people. Professionally, I now have a better understanding of concepts and a richer vision of company management. I've also developed a greater capacity for analysis."

We highlight that participation in a business school program is a significant resource for building a network and increasing access to a better job.

\section{Improvement in Education}

Education empowers women by improving their standard of living. We examine the role of business education as a catalyst for women's empowerment in management positions. To develop this measure, we can identify the variables which appear in Figure 7. 


\section{Figure 7}

Business education (media)

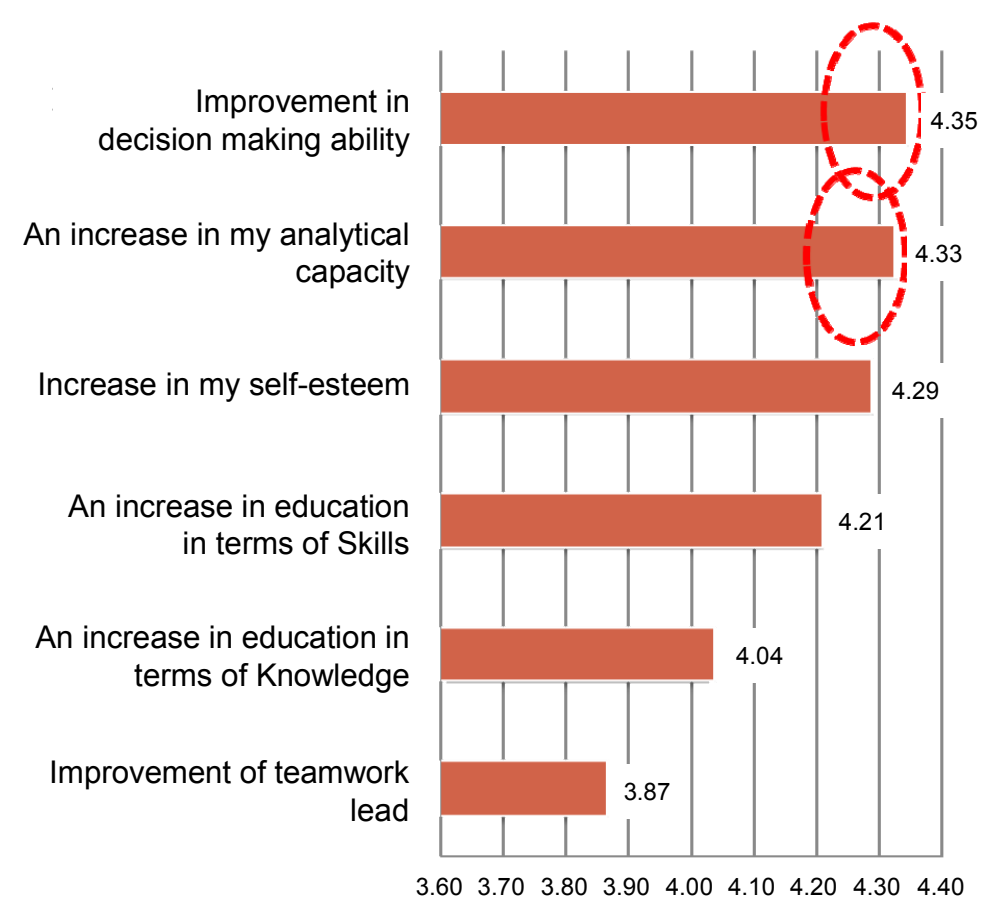

We have chosen the following quote from the survey respondents with respect to this construct.

"I have gained up-to-date knowledge, a global vision, decision-making methodology, networking, and best practices. I also improved my professional self-esteem, becoming aware of the knowledge and skills gained in the past. I appreciate the contacts, networking, I again feel how motivating it is to be close to sources of knowledge and I want to learn about everything and everyone. It has personally been an incredible experience."

\section{Work and Family Balance}

Parental leave for mothers, entitlement to take time off from work to care for a sick child and part-time work have been implemented to an increasing extent, with positive results for maternity leave and part-time work. We have measured the improvement in the family-work balance through the variables shown in Figure 8. 


\section{Figure 8}

Work and Family balance (media)

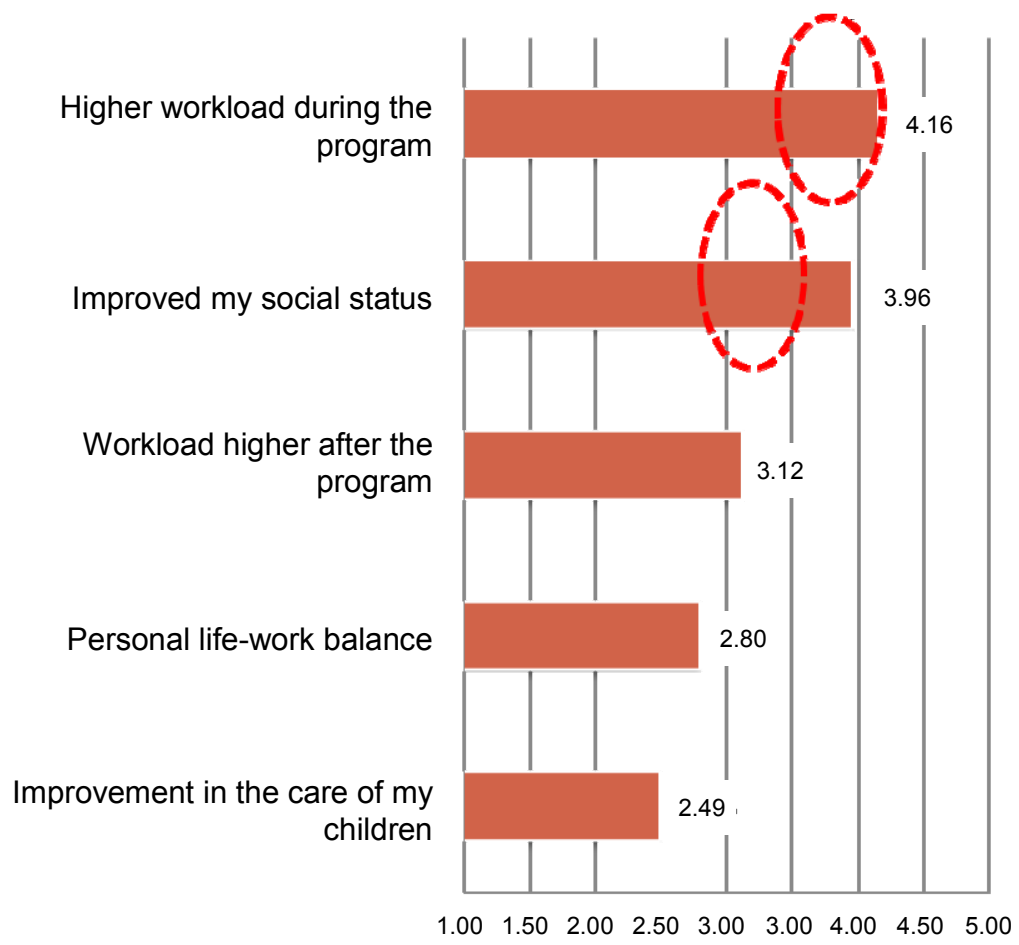

We found opposing views regarding achievement of a balance between work and family. For example, one of the participants said:

"The experience has been very positive even though the work-life balance is still pending in companies and business schools. It seems impossible to have a responsible position and have a family."

However, another participant has a positive opinion on the issue:

"The program has changed the way I manage both my professional and personal life. I have been given some excellent tools that have helped me start my development as a good manager. I have become aware, from having met certain professional women at the business school, that you can work and have children, even face times of change while pregnant or with newborns. But you have to know how to delegate, because we're not Superwomen, we are just women who want to enjoy their motherhood, their work, their family, their studies, and their leisure ...”

In this case, the quantitative data give a negative result, as an increase in workload during the program has not helped them attain this balance. However, the chance to take part in the program, improve their education, the networking etc., are all perceived as positive factors in finding a balance in their professional and family lives. 


\section{Experiment Results}

Upon finding that these descriptive data, despite their significance, are based solely on the possibility of undertaking a management education program, we asked ourselves what difference does the program make? Accordingly, in order to obtain find more conclusive results, we decided to conduct an experiment using both a control group and an experimental group with the goal of isolating what we could call "THE LIDERA EFFECT".

We wished to ascertain whether the effect existed and what were its chief expressions. Figure 9 lists the key features of the experimental and control groups.

\section{Figure 9}

Features of the control and Lidera groups.

$\begin{array}{ll}\text { CONTROL GROUP } & \text { LIDERA GROUP } \\ \text { • } 61 \text { Women } & \text { - } 64 \text { Women } \\ \text { - No Lidera grant } & \text { - Had Lidera grant } \\ \text { - IESE Business } & \text { - IESE Business } \\ \text { Management program } & \text { Management program } \\ \text { participants } & \text { participants } \\ & \\ \end{array}$

Thus, the question we ask in the questionnaire is: To what degree has the IESE program financed by LIDERA influenced your career? (Please number from 1 to 5, with 1 being very little and 5 very much). We found a significant mean difference $(t=1.839)$ in this question between the two groups. The Lidera group has a mean of 3.92 and the control group has a mean of 3.57 .

We also wanted to ascertain the differences between the two groups regarding the variables of the five constructs and we conducted a t test to find the significant differences. We summarize the findings in Figure 10 


\section{Figure 10}

Lidera Effect (Student's t-test: Comparison of two means)

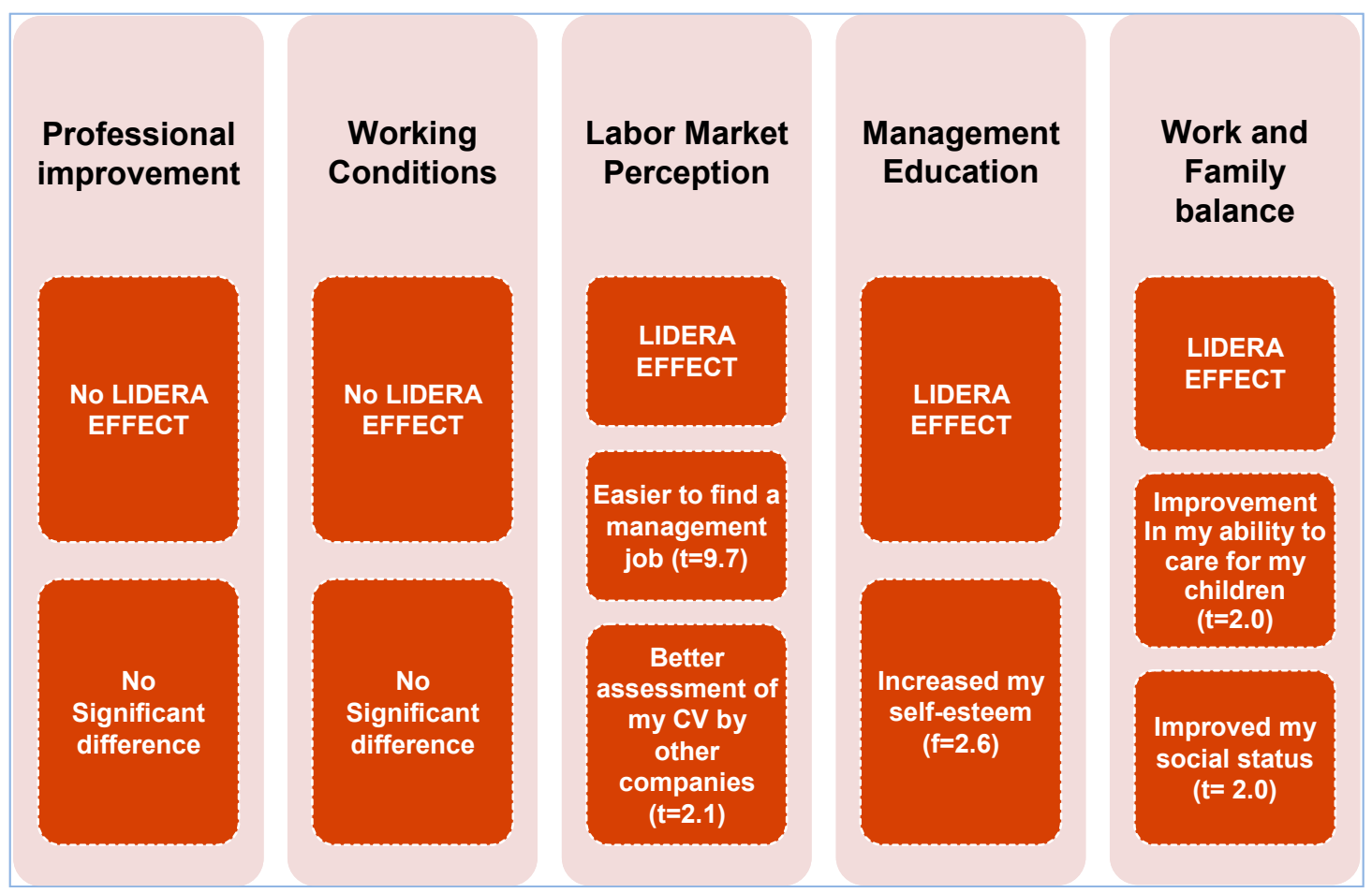

Having reached this stage of the research, we are in a position to answer the second research question: The LIDERA EFFECT exists and it has a positive differential impact on:

- The LIDERA women's perception of the Labor Market (LM) : Improvement in LM position as the Lidera women's CVs make their career changes easier: Extrinsic motivation

- The LIDERA women's management knowledge: positive attitude and self-esteem: Intrinsic motivation

"It was a personal challenge to undertake this type of program at the IESE, so personally it has brought me greater confidence and satisfaction."

Personal satisfaction and market recognition

- The LIDERA women's ability to balance work and family: Social status and child care: Transcendent motivation

\section{Conclusions}

National policy-making can be seen as a process of social learning, which is influenced by the actors' interests, ideas and perceptions, and the institutional framework, including past decisions and the rules of the political game (Hall, 1993, p. 275; Surel, 2002, p. 1). Introducing new policy programs aimed at fully mobilizing the female workforce proves to be extremely difficult, as national policymaking relies mainly on past decisions and policy procedures rather 
than changes in social and economic conditions (Hall, 1993, p. 277). Therefore, the success achieved in mobilizing the female workforce depends on national governments' ability to convince key actors on the need for intervention and the effectiveness of the policies proposed and to satisfy both them and the general public that the policies proposed address real problems in ways that are aligned with national values (Schmidt, 2002, p. 221). With respect to national values, these are defined here as the perceptions of policymakers and the general public regarding the division between provider and carer roles.

Moreover, as an extension of objective 1, we sought to identify the key success factors of gender mainstream initiatives such as the "Lidera project" and to explore their potential application in other territories. In addition, we wanted to identify the key success factors and target areas for improvement.

Summarizing, we can say that the LIDERA EFFECT exists and it has a positive, differential impact on:

- The LIDERA women's perception of the Labor Market (LM) : Improvement in LM position as the Lidera women's CVs make their career changes easier: Extrinsic motivation

- The LIDERA women's management knowledge: positive attitude and self-esteem: Intrinsic motivation

- The LIDERA women's ability to balance work and family: Social status and child care: Transcendent motivation

In this paper, we want to encourage research on this topic in Latin America and we view that such initiatives could contribute to enhance gender mainstreaming in fields other than those that have traditionally been approached from this perspective.

Few police forces in Latin America - or elsewhere - have undertaken gender mainstreaming within their institution. Nicaragua is the country that has most experience in this, although the National Civilian Police (PNC) of El Salvador and the National Police of Haiti (PNH), among others, have also taken steps towards gender mainstreaming. Mainstreaming programs have included a number of elements. Targeted recruitment of women is a central part of these initiatives. In El Salvador, prior to the Peace Accords, police were exclusively men, but following the founding of the PNC, women were also included in recruitment efforts and now make up 6\% of the total force (but 13\% of the highest ranking officers) (Rivera 2000). Although women always constituted a relatively large proportion of the National Police in Nicaragua since it was founded in 1979, specialized recruitment has also taken place. Women now make up 19\% of the force. Internal employment equity policies exist in Nicaragua regarding promotion and training and El Salvador has carried out a diagnostic study to provide the basis for its employment equity policy. As yet, no specific policies or mechanisms exist in any of the countries regarding pay equity or other employment equity issues such as sexual harassment, flexible hours, or daycare.

Most research regarding gender mainstreaming has consisted almost exclusively of diagnostic and other studies carried out as part of mainstreaming interventions. Gender mainstreaming in the police require intersectoral collaboration - particularly with the women's movement - both to ensure a focus on women's rights and a high quality of integrated services. Despite data and analysis limitations and the complexities of implementing WPS and gender mainstreaming, 
they are undoubtedly vital initiatives for improving women's citizenship and contributing to good governance. Gender mainstreaming improves the rights of women police in the Force and also, through increased transparency and transformed policies and programs, in the general population as well.

We also hope that the project will provide benefits in terms of the proportion of participants currently holding positions of responsibility in Madrid companies as a result of the training received. Lastly, we hope to determine whether the actions taken are enough and/or what other mainstream gender initiatives are needed to achieve the program's objectives and what are the factors that determine such achievement.

The paper's main limitation is that the analysis will not include everyone who has received a scholarship but only the participants in IESE courses. We are aware of the bias that this limitation entails and the need to obtain data from other business schools involved in the project. 


\section{References}

Baruch, Y. and M. Peiperl (2000), Career Management Practices: An Empirical Survey and Implications. Human Resource Management, 39:4, pp. 347-366, (Also published as a peerreviewed paper in the Proceedings of the British Academy of Management Meetings, 1997, This paper was awarded best paper in HRM at the British Academy of Management, 1997.)

Burke, R. (1994), Women in Corporate Management in Canadian Organizations: Slow Progress?, Executive Development, 7 (3), pp. 36-48.

Chandler, J. (2010), Women and men as managers: The importance of disappointment, Gender, Work \& Organization, 17 (5), pp. 590-611.

Dunphy, S. M. (2004), Demonstrating the value of diversity for improved decision making: The "wuzzle-puzzle" exercise, Journal of Business Ethics, 53 (4), pp. 325-331.

Devon, J. and D. Grayson (2005), "Cognitive and Affective Trust in Service Relationships," Journal of Business Research, 58:4 (April), pp. 500-507.

Hafner-Burton, Emilie and Mark Pollack (2000), Mainstreaming gender in the European Union, Journal of European Public Policy, 7 (3), Special issue, pp. 432-56.

Iversen, T. and R. Frances (2010), Women, Work, and Politics. The Political Economy of Gender Inequality, New Haven: Yale University Press.

Kelan, E. K. and R. D. Jones (2010), Gender and the MBA, Academy of Management Learning and Education, 9 (1), pp. 26-43.

Kevin I., Sara C., Deborah P. and H. Jim (2000), How Focused are the World's Top-Rated Business Schools on Educating Women for Global Management? How Focused are the World's Top-Rated Business Schools on Educating Women for Global Management? Journal of Business Ethics, 83, (1), pp. 65-83.

Leeming, A. and Y. Baruch (1998), The MBA as a Bridge over the Troubled Waters of Discrimination, Women in Management Review, 13 (3), pp. 95-104.

Liebert, U. and S. Sifft (Eds.) (2003), Gendering Europeanization, Series "Multiple Europes," Brussels: P.I.E. Peter Lang.

Mclnerney, M. L., Mader, D. D. and F. H. Mader (2010), Gender differences in responses to hypothetical business ethical dilemmas by business undergraduates, Journal of Diversity Management, 5 (1), pp. 37-41.

Pollack, M. A. and E. Hafner-Burton (2000), Mainstreaming gender in the European Union, Journal of European Public Policy, special issue on "Women, Power, and Public Policy," 7, pp. 432-456.

Randall, Vicky (1982), Women and Politics, (London: Macmillan).

Rees, Teresa (1998), Mainstreaming Equality in the European Union: Education, Training, and Labor Market Policies, New York: Routledge. 
Rees, Teresa (2002), The Politics of "Mainstreaming" Gender Equality in Breitenbach et al. (eds.), pp. 45-69.

Siemieñska, Renata (1990), Plec, zawod, polityka. Kobiety $w$ zyciu publicznym wPolsce [Gender, Occupation, Politics: women in public life in Poland] (Warsaw: Institute of Sociology, University of Warsaw).

Slater, D. J. and H. Dixon-Fowler (2010), The future of the planet in the hands of MBAs: An examination of CEO MBA education and corporate environmental performance, Academy of Management Learning and Education, 9 (3): pp. 429-441.

True, J. and M. Mintrom (2001), "Transnational Networks and Policy Diffusion. The Case of Gender Mainstreaming," International Studies Quarterly, 45: pp. 27-57.

Verloo, M. (2001), Another velvet revolution. Gender mainstreaming and the politics of implementation, IWM Working Paper 2001, IWM: Vienna.

Verloo, M. (2000), Making Women Count in the Netherlands," Sue Nott, Fiona Beveridge and Kylie Stephen (eds.), Making Women Count. Integrating gender into Law and Policymaking, Aldershot: Ashgate, pp. 49-77. 